\title{
Twenty-seven years of service research: a literature review and research agenda
}

\author{
Olivier Furrer and fie Yu Kerguignas \\ Department of Management, University of Fribourg, Fribourg, Switzerland \\ Cécile Delcourt \\ Department of Marketing HEC Liège, Management School, University of Liège, Liège, Belgium, and \\ Dwayne D. Gremler \\ Department of Marketing, College of Business, Bowling Green State University, Bowling Green, Ohio, USA
}

\begin{abstract}
Purpose - The growing service sector has experienced several revolutions that have transformed the way services are created and delivered. In parallel, services increasingly pique the interest of scholars, resulting in an expanding body of knowledge. Accordingly, it is time to reflect on extant service research, assess its boundaries, and think about its future. This paper aims to consider three research questions: How has service research evolved over the past 27 years? Which articles have most influenced the evolution of service research in the past 27 years? What are the most promising research themes for the future?

Design/methodology/approach - To answer these questions, the authors analyze the contents of 3,177 service research articles published in ten major academic journals between 1993 and August 2019. Multiple correspondence analysis reveals the evolution of key service research themes and their underlying relationships.

Findings - The research themes are organized in a growth-share matrix with four quadrants (stars, question marks, cash cows and pets) and also combine into four research clusters (human resource management, organizational behavior and strategy, technology, and operations and customer behavior and marketing). Together with a specified list of influential articles that have shaped the evolution of service research, these insights suggest an agenda for research.

Originality/value - Acknowledging the vast growth of service research, this study presents an up-to-date picture of the discipline and an agenda to stimulate continued research.
\end{abstract}

Keywords Emotion, Service innovation, Content analysis, Technology adoption, Ecosystems, Service dominant logic (SDL)

Paper type Research paper

\section{Introduction}

Any academic discipline should periodically reflect on its past, assess its boundaries and think about its future to legitimize its existence and advance the discipline. Among review articles that take stock of past service research and look ahead (Fisk et al., 1993; Furrer and Sollberger, 2007; Kunz and Hogreve, 2011; Ostrom et al., 2010, 2015), three methods are prevalent: expert-based surveys (Fisk et al., 2000; Ostrom et al., 2010, 2015), citation studies (Kunz and Hogreve, 2011; Wilden et al., 2017) and content analyses of published research (Fisk et al., 1993; Furrer and Sollberger, 2007; Nel et al., 2011).

Expert-based surveys provide introspections, reflections and glimpses about the history of service research and offer insightful prognoses about its future evolution (Fisk et al., 2000), though they also may suffer from interpretative or subjectivity biases (Koku, 2019; Kunz and Hogreve, 2011). Citation studies help alleviate these weaknesses and systematically examine the

The current issue and full text archive of this journal is available on Emerald Insight at: https://www.emerald.com/insight/0887-6045.htm

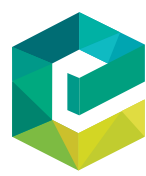

Journal of Services Marketing

34/3 (2020) 299-316

(C) Emerald Publishing Limited [ISSN 0887-6045]

[DOI 10.1108/JSM-02-2019-0078] evolution of the discipline with a more objective quantitative approach (Furrer et al., 2008), but they generally lack the richness of expert surveys (Ostrom et al., 2010). Content analyses, though they feature some potential subjectivity in their coding, are systematic and provide rich data. Therefore, these methods are complementary and offer alternative views on the content and evolution of a discipline (Kunz and Hogreve, 2011). In addition, they often propose different research agendas, based on their respective perspectives.

Although recent expert surveys and citation studies of service research have been published by Ostrom et al. (2010, 2015), Kunz and Hogreve (2011) and Wilden et al. (2017), the most recent content analysis of service research, conducted by Furrer and Sollberger (2007), is based on articles published between 1993 and 2003. Since 2003, service research has continued to grow and develop dramatically (Benoit et al., 2017). New and

The authors would like to thank Catrina Bur and Thibaud Salamin for their help with the preparation and coding of the data. They also would like to thank the two associate editors of this special issue, J. Joseph Cronin, Jr. and Duane Nagel, and the two anonymous reviewers for their support and insightful comments.

Received 15 February 2019

Revised 26 September 2019

7 February 2020

Accepted 26 February 2020 
influential topics, such as the service-dominant logic (SDL; Vargo and Lusch, 2004), service infusion (Brax, 2005), service science ( $\mathrm{Ng}$ et al., 2011), service ecosystems (Akaka and Vargo, 2015) and transformative service research (Anderson et al., 2013), have entered the service research vocabulary.

Thus, a systematic, updated content analysis of service research could be helpful for understanding its evolution and recommending an agenda for further research. The current study seeks to address three limitations of prior reviews:

1 a potential interpretation bias and the subjectivity of expert-based surveys;

2 the lack of richness of citation studies; and

3 the datedness of Furrer and Sollberger's (2007) content analysis, which does not include articles published in the past 16 years.

A content analysis of 3,177 articles published in ten major service and marketing research journals between 1993 and August 2019 seeks to answer three main research questions:

RQ1. How has service research evolved over the past 27 years?

RQ2. Which articles have most influenced the evolution of service research over the past 27 years?

RQ3. What are the most promising service research themes for the future?

Addressing these research questions establishes three contributions to service research. First, this article provides an overview of key service research themes and their developments over time, as well as the interrelationships among research themes. Second, this study provides a clear list of the most influential articles that have shaped the evolution of service research. Third, the study's findings suggest an agenda for future research for service scholars. These three contributions together constitute a comprehensive overview of the evolution of service research. In this respect, this study offers a holistic overview of service research covering nearly three decades.

The next section contains a brief review, focusing on extant studies that have examined the content and evolution of service research using the three identified approaches. After describing the method used to content analyze service research literature from 1993 to August 2019, this article presents the results, and finally, it concludes with an agenda for further research.

\section{Existing reviews of service research literature}

Three types of studies assess the content and evolution of service research literature: expert-based surveys, citation studies and content analyses.

\section{Expert-based surveys}

In 2000 and 2003, Fisk et al. gathered insights from ten leading service marketing experts who provided reflections on the future of the discipline (Fisk et al., 2000; Grove et al., 2003). With their answers to six questions about the core assumptions behind service marketing, these experts generated a rich commentary on service marketing evolution and thought. The divergence of the answers revealed the diversity of the discipline and suggested new avenues for research. Noting the recurring research themes, the authors propose that service research should consider:

- the interface between services and manufacturing;

- the impact of information technology and e-commerce;

- global service issues; and

- the scope, boundaries and conceptualization of service marketing.

Then in 2010, scholars from the Arizona State University's Center for Services Leadership articulated a set of global, interdisciplinary research priorities (Ostrom et al., 2010). Using input from academics around the world, as well as collaborations with business executives, they proposed ten research priorities. Their study affirms the broad, interdisciplinary and cross-functional characteristics of service research and calls for further actions to develop the landscape of the discipline. In recognition of the rapidly changing context in which services were being delivered and experienced, these priorities were updated five years later (Ostrom et al., 2015). This second set of service research priorities emerged from roundtable discussions and online surveys with more than 530 interdisciplinary researchers affiliated with nineteen research centers worldwide.

All these expert studies offer diversified, interesting insights regarding the past, present and future of service research. However, their potential subjectivity remains a core limitation, as outlined by the authors and others (Kunz and Hogreve, 2011).

\section{Citation studies}

Kunz and Hogreve (2011) review service literature using a citation-based approach, in which they compiled a list of all the articles published in nine top service research journals over 18 years (i.e. 1992-2009). They identify 168 service-specific articles cited at least twice per year. Their citation study reveals 16 research themes, and the systematic approach analyzes trends in citation patterns over time. However, by focusing only on citations, the analysis lacks the richness of experts' insights or content analyses.

To compensate for these weaknesses, some citation studies also rely on text mining tools (Wang et al., 2015). Wilden et al. (2017) use this approach to investigate SDL literature across two periods (2004-2008 vs. 2009-2015) and its potential for future developments. However, their study is focused solely on the SDL and does not examine the entire service discipline.

\section{Content analyses}

Content analyses provide a comprehensive review of a discipline. In their seminal study of early service marketing literature, based on analyses of more than 1,000 service research publications, Fisk et al. (1993) trace its evolution from its embryonic beginnings in 1953 to 1993. Picking up where Fisk et al. (1993) stopped, Furrer and Sollberger (2007) analyze service research published between 1993 and 2003. Their content analysis of more than 900 published service research articles reveals the evolution of service research, which they present on a two-dimensional map. The first dimension distinguishes studies emphasizing the management side of service research, versus those focused on the customer side. The second dimension also separates studies with a strategic 
focus from those that are more operational in nature. The results indicate that during 1993-2003, service research evolved toward being more strategic and customer oriented.

Four years later, considering articles published in fournal of Services Marketing over the period 1998-2008, Nel et al. (2011) determine several trends in research topics, identify some prolific authors and specify how service research has changed over time. However, their findings are limited to articles published in Fournal of Services Marketing. To identify the new topics that have emerged in service research since 2003 (or 2008), the current study offers an updated content analysis that covers a wide range of ten journals and a longer period (19932019), which also suggests areas that require further research.

\section{Method}

The method used to investigate service research literature over the past 27 years replicates that used by Furrer and Sollberger (2007), involving a content analysis of articles published in top service research journals from 1993 to August 2019. The year 1993 is the starting point because Fisk et al.'s (1993) analysis ended in 1992. Furrer and Sollberger (2007) also started their analysis in 1993, which provides a good basis for comparison.

A content analysis enables objective, systematic and quantitative consideration of a set of articles (Furrer et al., 2008). To identify the relationships among research themes and their evolution over time, the first step involves a multiple correspondence analysis (MCA) and mapping of the position of each research theme in a multidimensional space. Next the positions of these themes on the map have changed over the past 27 years are examined. Accordingly, the method involves several steps. First, relevant journals and articles are selected to be analyzed. Second, a list of key research themes categorizing service research is developed. Third, a coding procedure is established to identify one or, more research themes in each article. Fourth, the resulting data is subjected to statistical analysis, using MCA.

\section{Journal and article selection}

The number of service research articles published between 1993 and August 2019 is enormous. This article focuses on the same ten service research and general marketing journals that Furrer and Sollberger (2007) included Fournal of Services Marketing (JSM), fournal of Service Research (JSR), Fournal of Service Management (formerly International fournal of Service Industry Management; JoSM), Fournal of Marketing (JM), Fournal of Marketing Research (JMR), Fournal of Consumer Research (JCR), Fournal of Retailing (JR), Fournal of the Academy of Marketing Science (JAMS), Marketing Science (MS) and International fournal of Research in Marketing (IJRM). All articles published in the three key service research journals $(F S M, \mathcal{F S R}$ and FoSM) entered the analysis. For the remaining seven journals, only articles on service topics were included. The search engine for the ABI/Informs database identified articles that included the keywords "service" or "services" in their titles, abstracts or keywords (Furrer and Sollberger, 2007). This set included a few non-research articles (e.g. editorials, introductions to special issues) that were removed. This process resulted in a sample of 3,177 articles[1], including the 939 articles from Furrer and Sollberger's (2007) study.

\section{Theme selection}

Categorizing the content of the selected articles required creating a list of themes due to the large number of keywords identified by the authors in the ABI/Informs database. Accounting for the most recent developments in service research literature, the list of keywords and research themes represents an update of the versions developed by Furrer and Sollberger (2007). New keywords (in italics in Table I) were added by three service experts (coauthors) to the research themes developed by Furrer and Sollberger (2007). When a keyword appeared multiple times and did not seem to belong to any of the 27 existing research themes, it prompted the creation of a new theme. The six additional research themes that resulted were labeled by the three service experts, through intensive discussion, were service-dominant logic (Vargo and Lusch, 2008), emotions (Liu et al., 2019; Zablah et al., 2017), sales (Mai and Hoffmann, 2011), leadership (Popli and Rizvi, 2015), brand management (Brodie et al., 2009) and service climate (Bowen and Schneider, 2014). These six new research themes are consistent with emerging service research topics identified by Kunz and Hogreve (2011) and Ostrom et al. (2010, 2015). Thus, the procedure resulted in a total of 33 research themes (Table I).

\section{Coding procedure}

Following the methodology recommended by Furrer and Sollberger (2007) and Furrer et al. (2008), the categorization of the selected articles relied on multiple themes (when appropriate), rather than selecting a single dominating theme that would fail to reflect the cross-functional and interdisciplinary nature of service literature (Inkpen and Beamish, 1994). For the 939 articles published between 1993 and 2003, the data coded by Furrer and Sollberger provide satisfactory reliability (intercoder reliability $=0.91$; Perreault and Leigh, 1989), so reexamining them for this study mainly entailed assigning any of the six new themes to them, if necessary. Then the 2,238 articles published between 2004 and August 2019 were examined by two coders (coauthors). To ensure proper categorization, they followed a two-step procedure. First, using detailed coding instructions, including general instructions, the definition of each research theme, the keywords it contains (Table I), and the decision rules for assigning articles to multiple research themes, each coder categorized the articles independently based on detailed examinations of the articles' titles and abstracts. Second, the two coders resolved any disagreements through discussion. The check of the reliability of the coding procedure, using Perreault and Leigh's (1989) index, reveals a value of 0.92, which easily exceeds the recommended guideline of 0.70 (Cicchetti, 1994).

Among the 3,177 articles, 155 (4.9 per cent) have one theme, 745 (23.4 per cent) reveal two themes, 1,158 (36.4 per cent) have three, 718 (22.6 per cent) refer to four, 292 (9.2 per cent) have five, 78 (2.5 per cent) relate to six, 24 (0.8 per cent) involve seven and 7 ( 0.2 per cent) have eight or more themes. The overall mean is 3.19 themes per article, which is satisfactory and sufficient to compute a MCA (Furrer et al., 2008; Hair et al., 2010). 
Table I Service research literature: major themes and keywords

\begin{tabular}{|c|c|}
\hline Themes & Keywords \\
\hline After-sale services* & After-sale services, customer service, call centers, support services, warranties, guarantees \\
\hline Brand management** & Service brand, brand awareness, brand equity, brand image, brand extension, co-branding, brand association, brand identity \\
\hline $\begin{array}{l}\text { Business-to-business } \\
\text { (B2B) }\end{array}$ & Industrial buyers, outsourcing \\
\hline Communication* & Advertising, sales promotion, messages cues, media exposure, coupon, free samples, communication, image \\
\hline Competition & Pioneering advantage, competitive advantage, rivalry, benchmark, positioning \\
\hline Consumer behaviors & $\begin{array}{l}\text { Word-of-mouth, loyalty, customer referrals, switching behaviors, complaint, consumer search behaviors, jay customers, } \\
\text { dysfunctional customer behavior, repurchase intentions, decision-making process, customer misbehavior, revenge }\end{array}$ \\
\hline Customer satisfaction & Satisfaction, disconfirmation, dissatisfaction, pleasure, arousal, consumer comfort, delight \\
\hline Distribution* & Franchising, e-tailing, retailing, service delivery system, supply chain \\
\hline Emotions** & Emotional contagion, emotions, emotional bonding, emotional labor, anger \\
\hline Employee* $^{*}$ & $\begin{array}{l}\text { Front-line employees, job autonomy, job satisfaction, customer orientation, internal marketing, internal marketing orientation, } \\
\text { work organization, work stress, customer contact, employee sabotage, organizational citizenship behavior }\end{array}$ \\
\hline $\begin{array}{l}\text { Environmental } \\
\text { context }\end{array}$ & Service context, environment, service ecosystem \\
\hline Ethics & $\begin{array}{l}\text { Social responsibility, legality, fairness, bribery, privacy concerns, ecology, environment, stakeholders, code of practice, corporate } \\
\text { social responsibility, CSR, transformative services }\end{array}$ \\
\hline Leadership ${ }^{* *}$ & Leadership, leader, entrepreneur \\
\hline Innovation & $\begin{array}{l}\text { Pioneer advantages, technological innovation, new service development, time-to-market, new product adoption, new product } \\
\text { diffusion }\end{array}$ \\
\hline International* & $\begin{array}{l}\text { Cross-cultural management, culture, ethnocentrism, country of origin, cross national, global, export, national regulations, } \\
\text { privatization, foreign market entry }\end{array}$ \\
\hline Methodology/theory* & $\begin{array}{l}\text { Critical incident, statistical analysis, case studies methodology, experiment, scale assessment, scale development, measurement } \\
\text { issues, questionnaire, ethnography, theory, theory development }\end{array}$ \\
\hline Non-profit services & Public services, voluntary service, non-profit organization \\
\hline $\begin{array}{l}\text { Operation/service } \\
\text { design }\end{array}$ & $\begin{array}{l}\text { Waiting time, business process management, service mapping, service design, service delivery systems, blueprinting, facility, } \\
\text { capacity, demand, queuing, logistics, order processing, capacity management, process re-engineering, service science }\end{array}$ \\
\hline Performance & $\begin{array}{l}\text { Profitability, efficiency, productivity, cost, long term performance, service effectiveness, customer equity, customer lifetime value, } \\
\text { customer equity, financial performance }\end{array}$ \\
\hline Price/value & Capacity management, yield management, tipping, optimal pricing, subscription-based services, service value, value, price, pricing \\
\hline Sales** & Sales techniques, contract, negotiation, selling, buyer-seller relationships \\
\hline Service climate* & Service culture, organizational culture, climate \\
\hline $\begin{array}{l}\text { Service dominant } \\
\text { logic }^{* *}\end{array}$ & SDL, customer co-creation, co-participation, co-production \\
\hline Service encounters & $\begin{array}{l}\text { Experience, customer contact, face-to-face, interaction, customer comfort, critical incidents, service experience, customer } \\
\text { experience, customer engagement }\end{array}$ \\
\hline Service failure* & Justice (procedural, distributive, interactional), complaint management, service failure, apology, compensation, perceived fairness \\
\hline Service offering & Service level, loyalty programs, customer requirement, tailoring, product's service attributes \\
\hline Service quality & Consumer evaluations, expectancy, expectations, perceptions, quality, SERVPERF, SERVQUAL scale \\
\hline Strategy & $\begin{array}{l}\text { Segmentation, customer profiling, marketing planning, strategic planning, growth strategy, market strategy, customer retention } \\
\text { strategies, differentiation strategy, market entry, targeting, market orientation }\end{array}$ \\
\hline Tangibles* & $\begin{array}{l}\text { Tangible clues, servicescape, physical surroundings, surroundings, infrastructures, location, layout, atmospherics, service physical } \\
\text { environment }\end{array}$ \\
\hline Technology/e-service* & $\begin{array}{l}\text { Information technology, technology-based self-service, ATM, self-service bias, electronic distribution channels, Internet, online } \\
\text { services, e-commerce, cyberservices, interactive, interactive marketing, telemarketing, eCRM, e-tailing, technology infusion, service } \\
\text { robots, blockchain technology, the Internet of Things, smart services, access-based services }\end{array}$ \\
\hline $\begin{array}{l}\text { Typology } \\
\text { (types of services) }\end{array}$ & $\begin{array}{l}\text { Classification, classifying, search services, experience services, credence services, types of services, typology good vs. services, } \\
\text { framework developed, paradigm, servitization, service infusion }\end{array}$ \\
\hline $\begin{array}{l}\text { Relationship } \\
\text { marketing* }\end{array}$ & $\begin{array}{l}\text { Relationship, customer retention, relationship management, long-term relationship, commitment, trust, CRM, account } \\
\text { management, switching costs }\end{array}$ \\
\hline Usage/purchase & Consumption, preference, decision \\
\hline
\end{tabular}

Notes: The themes and keywords have been adapted from those of Furrer and Sollberger (2007). Keywords in italics are newly added. *Adapted label. **New theme 


\section{Multiple correspondence analysis}

To analyze the relationships of the various research themes and their evolution over time, the MCA (Furrer and Sollberger, 2007) adopts the homogeneity analysis by means of alternating least squares (HOMALS) procedure in SPSS 25 (Meulman and Heisen, 2017). This exploratory data analysis technique supports the exploration and analysis of frequency tables to detect structures in the relationships of nominal variables (i.e. presence or absence of themes) (Blasius and Greenacre, 2006; Hoffman and Franke, 1986). MCA has been used in other studies to map the evolution of the content of research fields (Furrer and Sollberger, 2007; Furrer et al., 2008; Huber et al., 2014). For the present study, the rows of the frequency table correspond to the 3,177 articles, and the columns contain the 33 research themes. If two rows have similar patterns of themes, they appear close together in the correspondence analysis plot and reveal close coordinates on dimensions that account for variance (Bendixen, 1995). The results of the MCA can be plotted on multidimensional maps to identify the relative positions of articles and research themes.

The selection of the optimal number of dimensions relied on the eigenvalue curve criteria recommended by Hoffman and De Leeuw (1992). However, as Kaciak and Louviere (1990) note, the proportion of the total variance explained by the dimensions is often small and underestimates map quality (Lebart et al., 1984). The results of the scree plot test suggest a two-dimensional space for the graphical presentation of the data (the first four eigenvalues are 1.85, 1.62, 1.44 and 1.33).

\section{Results}

\section{Research themes' evolution over time}

To examine the evolution of service research, the 27 years of publications was divided into three equally long time periods (nine years). This division provides enough articles per research theme per period to ensure the reliability of the analysis. The first period (1993-2001) involves 702 articles, the second period (2002-2010) contains 1,208 articles and the third period (2011-2019) consists of 1,267 articles (Table II).

Table II provides the number and percentage of articles per theme and per period, as well as the compound growth rate of the number of articles per theme over the three periods. The most researched themes have changed over time. During the first period, the most researched theme is "service quality," with 220 articles (it appears 11.1 per cent of the time in the articles published during 1993-2001), followed by "consumer behavior" (170 articles, 8.6 per cent), "customer satisfaction" (162 articles, 8.2 per cent), "performance" (144 articles, 7.2 per cent), "strategy" (107 articles, 5.4 per cent) and "employees" (91 articles, 4.6 per cent). During the second period, the most researched theme became "consumer behavior," with 410 articles (10.5 per cent), followed by "customer satisfaction" (310 articles, 7.9 per cent), "service quality" (253 articles, 6.5 per cent), "performance" (245 articles, 6.3 per cent), "relationship marketing" (225 articles, 5.8 per cent), "strategy" (195 articles, 5.0 per cent), "employees" (164 articles, 4.2 per cent) and "technology/eservice" (158 articles, 4 per cent). Finally, in the third period, the most researched theme remains "consumer behavior," with 411 articles (9.7 per cent), followed by "relationship marketing" (266 articles, 6.3 per cent), “employees" (228 articles, 5.4 per cent), "customer satisfaction" (223 articles, 5.2 per cent), "technology/e-service" (212 articles, 5.0 per cent), "performance" (211 articles, 5.0 per cent) and "service encounters" (205 articles, 4.8 per cent).

These figures indicate that some research themes, such as consumer behavior and customer satisfaction, have maintained similar levels of research attention, whereas other themes, such as service quality and strategy, have declined in interest in more recent years. In particular, service quality, the most researched theme during the first period, dropped to 14 th position (150 articles, 3.5 per cent) by the third period. In contrast, both relationship marketing and technology/e-service increased in frequency during the second period. Specifically, relationship marketing ranked eighth in Period 1, moved to fifth in Period 2 and made it to second place in Period 3. The growth of the technology/e-service research theme was even faster, from the 18th position in Period 1, to the eighth and fifth positions in Periods 2 and 3, respectively.

\section{Growth-share matrix}

To understand the relative progression of some research themes and the emergence of new ones, a two-by-two matrix helps classify research themes according to the overall number of articles (horizontal dimension) and their growth rate over the entire period (vertical dimension) (Figure 1). These two dimensions resemble those in the famous Boston Consulting Group matrix, so the four resulting quadrants take the labels cash cows, stars, question marks and pets. Cash cows prompt many articles but have a relatively low growth rate. They are mature research themes (e.g. service quality, customer satisfaction, performance, strategy) that were especially popular in the first period of the analysis, and though that popularity has somewhat faded, they remain prominent. Stars started to receive more attention during the second time period and still enjoy a healthy growth rate. The four research themes in this group are SDL, technology/e-service, relationship marketing and emotions. Another four themes with a relatively small number of articles are classified as question marks, as they also exhibit a strong growth rate, suggesting their potential to either become stars or else collapse as fads. The themes so categorized are environmental context, innovation, leadership and ethics. Finally, pets are research themes that seem peripheral to service research. These themes, which comprise a relatively small number of articles and exhibit a low growth rate, include brand management, service climate, tangibles, non-profit services, competition, sales and negotiation, B2B and after-sales services.

\section{The multiple correspondence analysis results}

The results of the MCA indicate the positions of each research theme on a two-dimensional map (Figure 2), in which proximities between two research themes reflect the extent to which they share content (Furrer et al., 2008), and the size of the point represents the proportional number of articles containing a given theme. The dimensions of the map indicate characteristic "poles" of topical orientation within service research literature (Furrer and Sollberger, 2007). The first (horizontal) dimension separates themes that emphasize research with an organization focus (left side) from those that 
Table II Number and percentage of articles per theme and per period

\begin{tabular}{|c|c|c|c|c|c|c|c|c|c|}
\hline \multirow[b]{2}{*}{ Theme } & \multicolumn{2}{|c|}{$\begin{array}{c}1993-2001 \\
(n=702)\end{array}$} & \multicolumn{2}{|c|}{$\begin{array}{l}2002-2010 \\
(n=1,208)\end{array}$} & \multicolumn{2}{|c|}{$\begin{array}{l}2011-2019 \\
(n=1,267)\end{array}$} & \multicolumn{2}{|c|}{$\begin{array}{c}\text { Total } \\
(n=3,177)\end{array}$} & \multirow{2}{*}{$\begin{array}{l}\text { Growth } \\
\text { CGR (\%) }\end{array}$} \\
\hline & $\#$ & $(\%)$ & $\#$ & $(\%)$ & $\#$ & $(\%)$ & $\#$ & $(\%)$ & \\
\hline Service dominant logic & 1 & 0.1 & 49 & 1.3 & 173 & 4.1 & 223 & 2.2 & 457.2 \\
\hline Ethics & 8 & 0.4 & 26 & 0.7 & 108 & 2.5 & 142 & 1.4 & 138.1 \\
\hline Environmental context & 19 & 1.0 & 86 & 2.2 & 108 & 2.5 & 213 & 2.1 & 78.5 \\
\hline Emotions & 31 & 1.6 & 97 & 2.5 & 160 & 3.8 & 288 & 2.8 & 72.8 \\
\hline Innovation & 24 & 1.2 & 64 & 1.6 & 119 & 2.8 & 207 & 2.0 & 70.5 \\
\hline Technology/e-service & 43 & 2.2 & 158 & 4.0 & 212 & 5.0 & 413 & 4.1 & 70.2 \\
\hline Leadership & 5 & 0.3 & 13 & 0.3 & 17 & 0.4 & 35 & 0.3 & 50.4 \\
\hline Relationship marketing & 79 & 4.0 & 225 & 5.8 & 266 & 6.3 & 570 & 5.6 & 49.9 \\
\hline Service encounters & 62 & 3.1 & 118 & 3.0 & 205 & 4.8 & 385 & 3.8 & 49.0 \\
\hline Brand management & 23 & 1.2 & 77 & 2.0 & 76 & 1.8 & 176 & 1.7 & 48.9 \\
\hline Service climate & 9 & 0.5 & 18 & 0.5 & 28 & 0.7 & 55 & 0.5 & 46.0 \\
\hline Methodology/theory & 63 & 3.2 & 153 & 3.9 & 195 & 4.6 & 411 & 4.1 & 45.7 \\
\hline Price/value & 54 & 2.7 & 126 & 3.2 & 157 & 3.7 & 337 & 3.3 & 42.7 \\
\hline Service failure & 42 & 2.1 & 108 & 2.8 & 121 & 2.8 & 271 & 2.7 & 42.3 \\
\hline Service offering & 30 & 1.5 & 114 & 2.9 & 86 & 2.0 & 230 & 2.3 & 42.1 \\
\hline Tangibles & 20 & 1.0 & 71 & 1.8 & 54 & 1.3 & 145 & 1.4 & 39.2 \\
\hline Employees & 91 & 4.6 & 164 & 4.2 & 228 & 5.4 & 483 & 4.8 & 35.8 \\
\hline Consumer behaviors & 170 & 8.6 & 410 & 10.5 & 411 & 9.7 & 991 & 9.8 & 34.2 \\
\hline Distribution & 46 & 2.3 & 78 & 2.0 & 101 & 2.4 & 225 & 2.2 & 30.0 \\
\hline Communication & 77 & 3.9 & 126 & 3.2 & 167 & 3.9 & 370 & 3.6 & 29.4 \\
\hline Usage/purchase & 53 & 2.7 & 121 & 3.1 & 108 & 2.5 & 282 & 2.8 & 26.8 \\
\hline Typology (types of services) & 68 & 3.4 & 70 & 1.8 & 100 & 2.4 & 238 & 2.3 & 13.7 \\
\hline Performance & 144 & 7.2 & 245 & 6.3 & 211 & 5.0 & 600 & 5.9 & 13.6 \\
\hline Strategy & 107 & 5.4 & 195 & 5.0 & 155 & 3.6 & 457 & 4.5 & 13.1 \\
\hline International & 63 & 3.2 & 95 & 2.4 & 91 & 2.1 & 249 & 2.5 & 13.0 \\
\hline Customer satisfaction & 162 & 8.2 & 310 & 7.9 & 223 & 5.2 & 695 & 6.8 & 11.2 \\
\hline Operation/service design & 84 & 4.2 & 107 & 2.7 & 82 & 1.9 & 273 & 2.7 & -0.8 \\
\hline Non-profit services & 27 & 1.4 & 15 & 0.4 & 26 & 0.6 & 68 & 0.7 & -1.3 \\
\hline Business-to-business (B2B) & 44 & 2.2 & 75 & 1.9 & 41 & 1.0 & 160 & 1.6 & -2.3 \\
\hline Sales & 41 & 2.1 & 59 & 1.5 & 34 & 0.8 & 134 & 1.3 & -6.0 \\
\hline Competition & 34 & 1.7 & 50 & 1.3 & 27 & 0.6 & 111 & 1.1 & -7.4 \\
\hline Service quality & 220 & 11.1 & 253 & 6.5 & 150 & 3.5 & 623 & 6.1 & -12.0 \\
\hline After-sale services & 43 & 2.2 & 32 & 0.8 & 12 & 0.3 & 87 & 0.9 & -34.7 \\
\hline
\end{tabular}

Notes: The research themes are ordered by their growth rate over the entire period. CGR = compound growth rate, which is a measure of growth over multiple time periods computed as $\left(N_{\text {last }} / N_{\text {first }}\right)^{1 / p}-1$, where $N_{\text {last }}$ is the number of articles during the last time period, $N_{\text {first }}$ is the number of articles during the first period, and $p$ is the number of periods

adopt a customer focus (right side). The second (vertical) dimension separates strategic-level themes (top) from operational-level ones (bottom).

To facilitate the interpretation of the relative positions of the research themes, the analysis next identifies four service research clusters. The first cluster (upper left quadrant of the map) features studies at the strategic level that examine service phenomena from an organizational perspective. It comprises the following research themes: leadership, service climate and employees. Thus, it takes the label human resource management (HRM). The second cluster, on the left side of the figure, includes studies that adopt an organizational perspective, dominated by such research themes as strategy, performance, service offering and brand management, so its label is organizational behavior and strategy (OBS). The third cluster at the bottom of the map tends to be operational in nature and focuses on research themes such as distribution, price/value, usage/purchase and communication, so it is the technology and operations (TO) cluster. Finally, on the right side of the map, the largest, fourth cluster takes a customer perspective on research themes such as service quality, customer satisfaction, consumer behaviors and relationship marketing, so it is labeled customer behavior and marketing $(C B M)$.

\section{Evolution in interrelationships among research themes}

By computing the position of each research theme for each of the three periods, according to the centroid of articles contained in the research theme published during each period (Bendixen, 1995), it is possible to evaluate the extent and the direction of change in the interrelationships of the research themes. As indicated in Figure 3, a position on the map for a given period is the average position of the coordinates of all articles that contain the research theme published during that 
Figure 1 Growth-share matrix of the service research themes

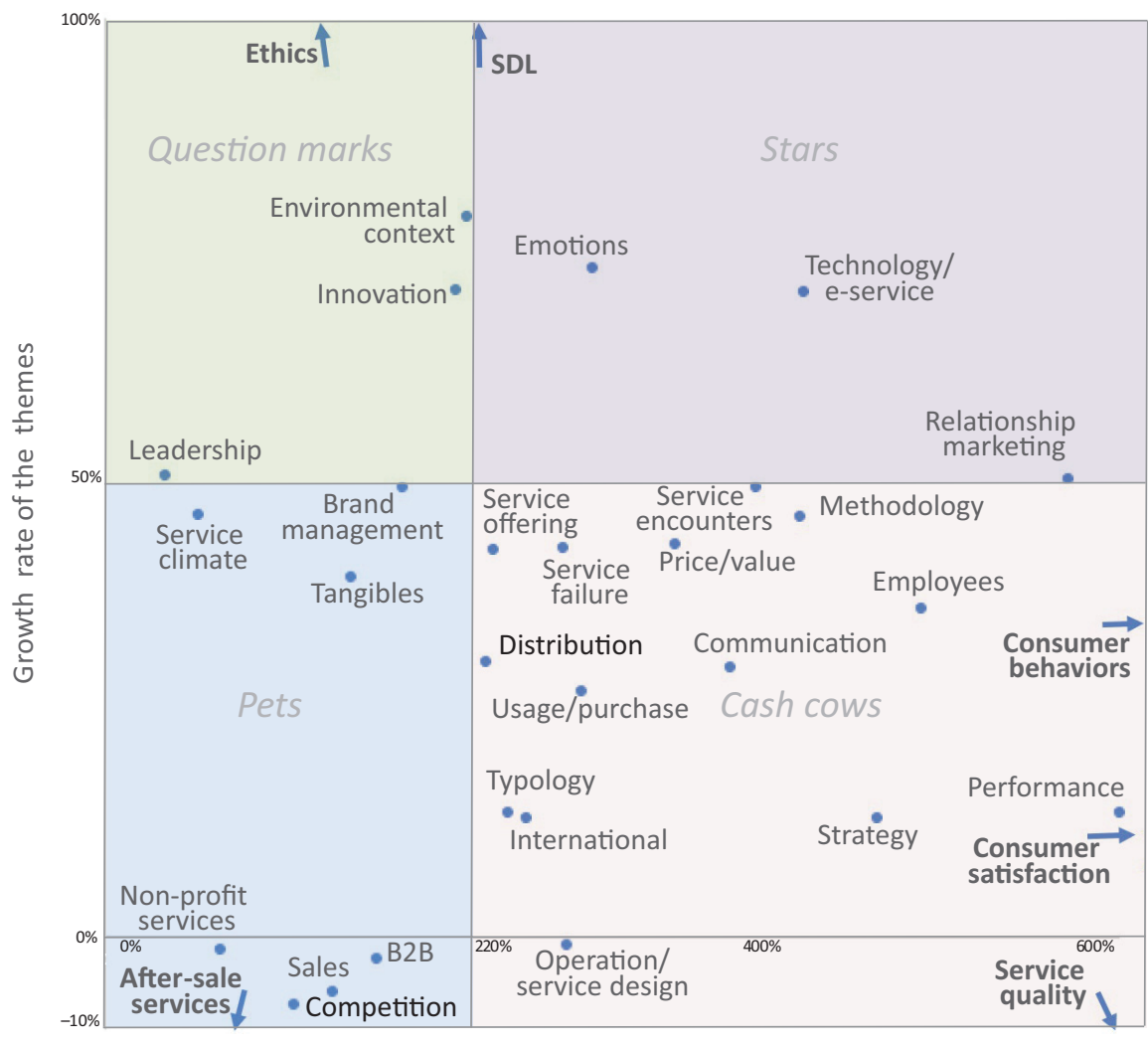

Number of articles of related themes

Notes: The six themes in bold font are located outside of the map presented above. The arrows indicate the direction of the position of each theme as follows: Service dominant logic $212(\mathrm{x}), 460 \%$ (y); Ethics $132(\mathrm{x}), 144.2 \%$ (y); Consumer behaviors 963 (x), 48.2\% (y); Customer satisfaction 680 (x), 19.3\% (y); Service quality 619 (x), -4.2\% (y); After-sale services $86(\mathrm{x}),-31.9 \%(\mathrm{y})$.

period. The arrows represent the direction of evolution of each theme. Their length signals the extent of changes in the themes.

Figure 3 reveals that the position of some research themes has not changed much over time, whereas others have moved substantial distances across the map (extent of change) or in different directions (direction of change). Most service research themes have not moved much, indicating their relative stability or maturity over time. However, two themes - SDL and ethics - exhibit significant changes in their positions over time.

The SDL theme, popular since the publication of Vargo and Lusch's (2004) introduction of the concept, moved from a peripheral position on the right side of the map in Period 1 to a more central position, largely due to many early SDL studies that focused on value cocreation. More recent SDL research tends to take a more strategic and organizational perspective (Vargo and Lusch, 2016). The ethics theme moved from a central position toward the customer pole on the right side of the map due primarily to the emergence of two increasingly popular keywords included in this research theme: corporate social responsibility and transformative service research. Both topics are more customer-oriented relative to traditional organizational and strategic approaches to business ethics.
In terms of the directions of change, clusters of research themes move in different directions. Those in the HRM cluster, such as leadership, service climate and employees, move toward the upper right side. Research in these areas has become more strategic and more consumer-oriented over time. Research themes from the OBS cluster, including innovation, strategy, sales and performance, tend to move from the left toward a more central position, at the core of the map of service research literature. This shift indicates that these research themes, traditionally studied from an organizational perspective, now involve more consumer-oriented approaches. Furthermore, it indicates that strategic and organizational issues, critical to service practice, have become more mainstream. The TO cluster, which includes distribution, technology/e-service, price/value and communication, shifts from the center of the map toward the lower right, indicating a stronger consumer orientation and operational perspective. That is, service research into the interplay of technology and operations recently has focused on operational, rather than strategic, issues enabled by the development of new technological tools. Finally, to the right side, research themes from the CBM cluster, which includes service failure, service encounters and customer satisfaction, move 
Figure 2 The service research literature: multiple correspondence analysis results

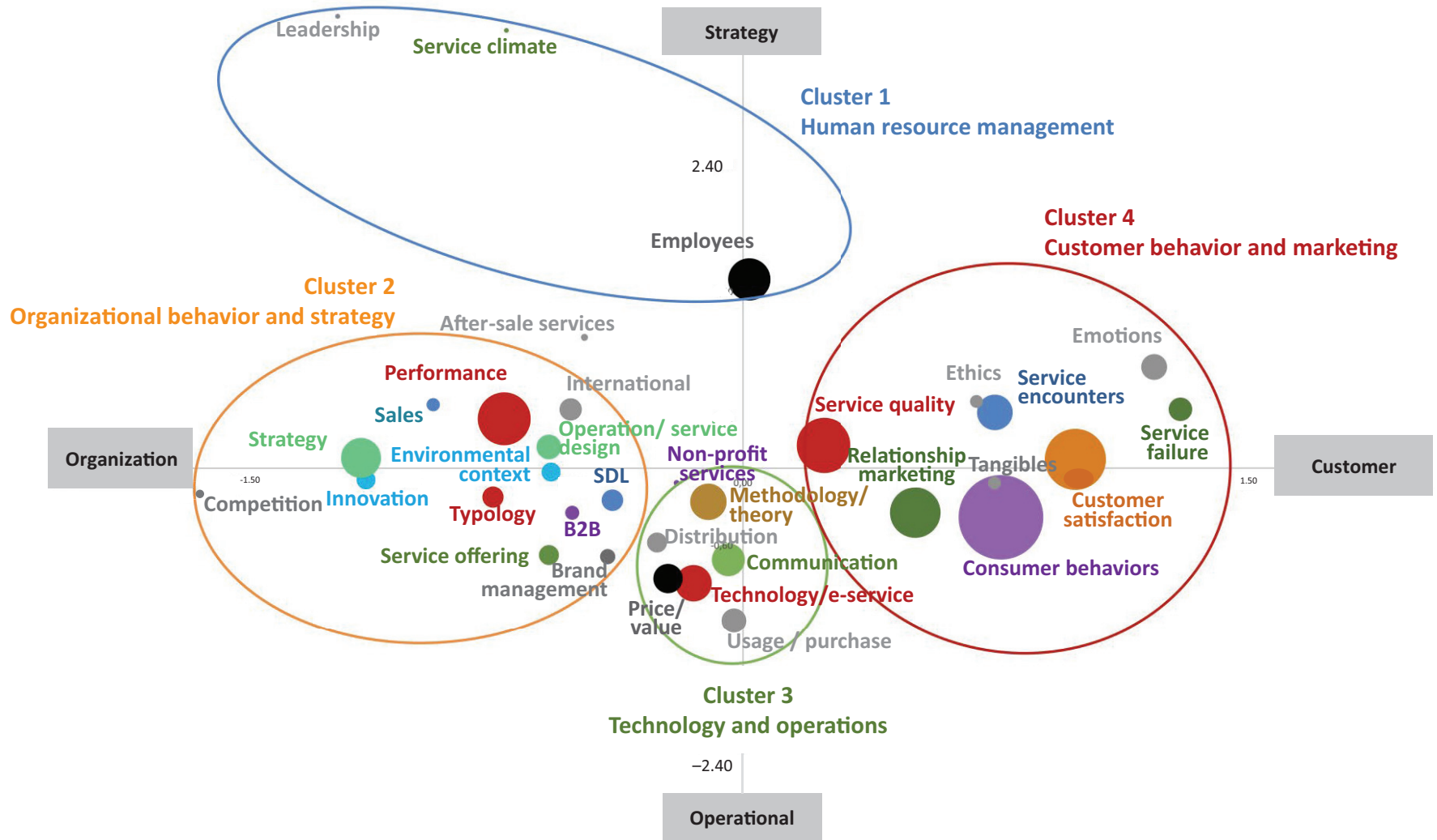

Note: The size of the point represents the proportional number of articles contained in a given theme

slightly to the left (toward the center) during third period (20112019), after having moved away from this center during the second period (2002-2010). Following a strong focus on customer behavior, more recent research has adopted a more organizational perspective.

\section{Influential papers}

Influential studies largely determine the evolution of a research discipline (Berry and Parasuraman, 1993). To define and measure the influence of a research article, the number of citations per year provides a viable option (Furrer and Sollberger, 2007; Furrer et al., 2008), because the total number of citations is time dependent, and older articles are likely to have been cited more frequently (Stremersch et al., 2015). This approach thus can identify influential service research articles published between 1993 and 2019 and rank them according to the number of citations in the SSCI citation database, as accessed through the Clarivate Web of Science on July 3, 2019. The Web of Science database, rather than Google Scholar, controls better for citation quality, because it contains only citations from top-ranked academic journals[2]. Table III lists the 41 most influential articles, with their total citations and number of citations per year[3].

In terms of citations per year, the top of this list features four papers that average more than 100 citations per year: two famous SDL articles, Vargo and Lusch (2004) with 295 citations per year and Vargo and Lusch (2008) with 175 citations per year, as well as two service quality contributions, namely, Zeithaml et al. (1996) with 151 citations per year and Cronin et al. (2000) with 111 citations per year. Among the top 41 influential articles, 15 were published during the first period (1993-2001), 17 during the second period (2002-2010) and 9 in the third (2011-2019).

The 15 articles published during the first period have had a long-lasting influence, reaching the status of seminal articles (Thompson, 2010). Each is a "must cite" for its central research theme: Zeithaml et al. (1996), Cronin et al. (2000), Brady and Cronin (2001) and Boulding et al. (1993) in service quality; Garbarino and Johnson (1999), Tax et al. (1998), Moorman et al. (1993), Gwinner et al. (1998) and Berry (1995) in relationship marketing; Anderson et al. (1994), Fornell et al. (1996) and Anderson and Sullivan (1993) in customer satisfaction; Smith et al. (1999) in service failure and recovery; Meuter et al. (2000) in self-service technology; and Keaveney (1995) in customer switching behavior.

Among the 17 influential articles published during the second period (2001-2009), some are particularly noteworthy. The two papers at the top of the list, by Vargo and Lusch (2004, 2008), reflect the critical impact of the SDL on service research. The popularity of Payne et al.'s (2008) study of the cocreation of value - a concept central to the SDL - supports the crucial importance of this topic in service research. Articles by Parasuraman et al. (2005) and Zeithaml et al. (2002) on e-service quality also have encouraged the development of 
Figure 3 Map of the evolution of the research themes over time

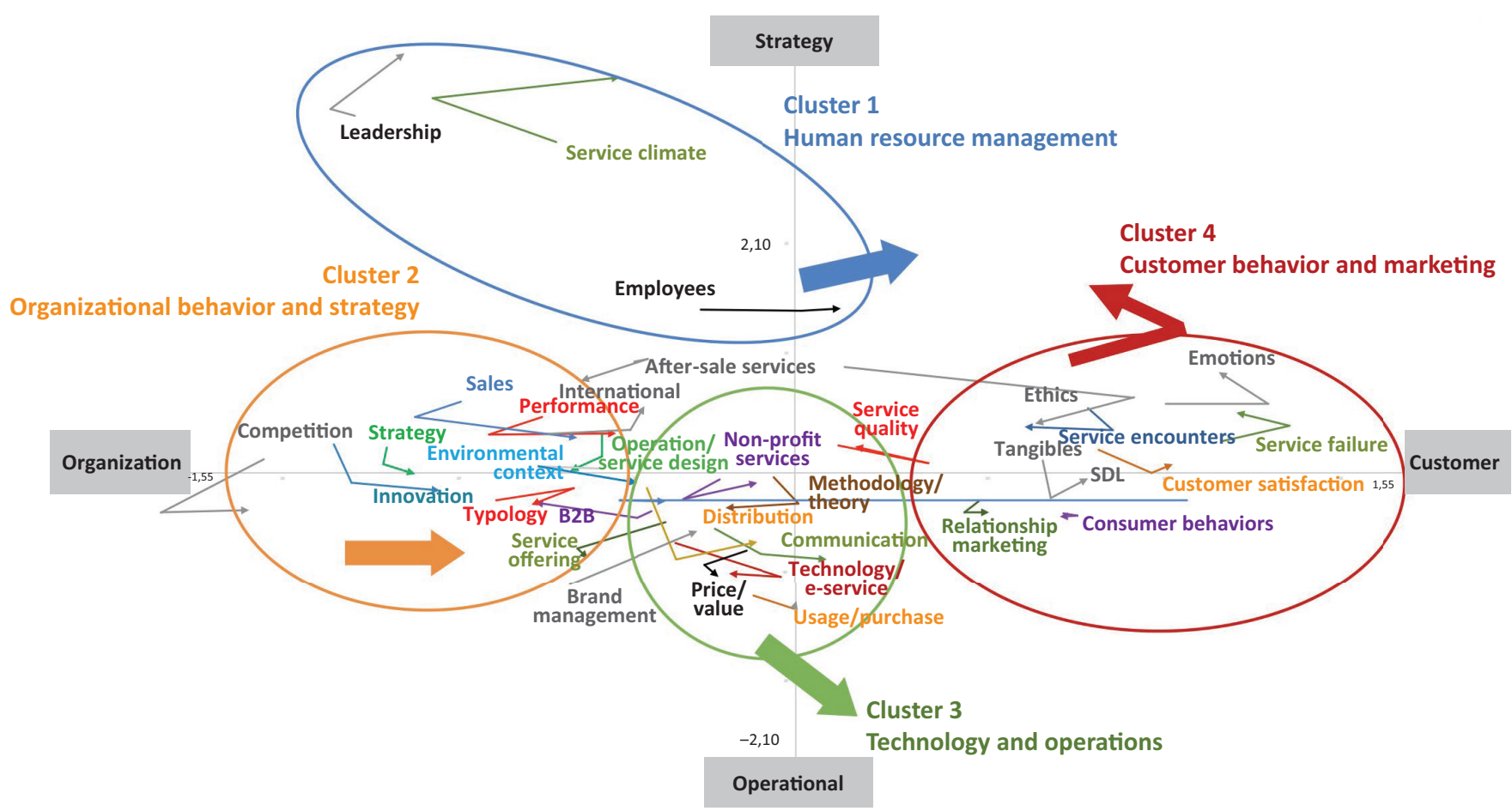

Note: The start the arrow indicates the time period 1, the bend of the arrow indicates the time period 2, and the point of the arrow indicates the time period 3

research into digital services and the role of technology. Sirdeshmukh et al. (2002) and Palmatier et al. (2006) both have encouraged the development of relationship marketing research, and Rust et al. (2004) and Oliva and Kallenberg (2003) have had strong impacts on strategic and performancerelated aspects of service research.

Particularly influential articles from the most recent period include Vargo and Lusch (2016) and Hollebeek et al. (2019), pertaining to the SDL, as well as Edvardsson et al. (2011) and Grönroos and Voima (2013), which deal with value cocreation within the SDL. Considering the many citations they have accumulated in a short time, these four articles clearly have had strong influences on service research already. Also, in this third period, Lemon and Verhoef (2016) address customer experience. Brodie et al. (2011) study customer engagement behavior, Bolton et al. (2013) consider the use of social media by millennials, Zervas et al. (2017) describe the sharing economy and Ostrom et al. (2015) propose an agenda for future service research.

\section{Directions for service research: a research agenda}

These findings, based on the analysis of 3,177 service research articles, provide insights to suggest research directions and a research agenda based on four key insights derived from the current research: the growth-share matrix (Figure 1), the number and percentage of articles per theme and per period (Table II), influential articles published between 1993 and
2019 (Table III) and the evolution of service research over time (Figure 3). Information from Figure 1 indicates three major research themes. Further, combining Figure 1 with Table II reveals two question marks that deserve further research attention. These two elements inform the suggested research agenda. The influential service research articles (Table III) and information depicted in Figure 3 with respect to each theme also prompt recommendations of questions for further research. Accordingly, this discussion centers around the three themes identified in the stars category (technology/e-service, service-dominant logic and emotions) and two question marks (innovation and environmental context) [4]. These five service research areas offer great potential, together with some notable research questions (Table IV). Next, we detail the future directions for the three themes in the stars category followed by the two question marks.

\section{Technology/e-service}

Due to technological innovations and the digital transformation of the service sector, a variety of phenomena have dramatically changed service delivery, as detailed by studies in the technology/e-service theme. Some groundbreaking innovations include service robots (Čaić et al., 2018; Van Doorn et al., 2017; Wirtz et al., 2018), artificial intelligence (AI) (Huang and Rust, 2018; Larivière et al., 2017), blockchain technology (Tapscott and Tapscott, 2017), the Internet of Things (Ng and Wakenshaw, 2017), smart services (De Keyser et al., 2019; Wünderlich et al., 2015) and access-based services (Hazée 
Table III Influential service research articles, 1993-2019a

\begin{tabular}{|c|c|c|c|c|c|}
\hline & Author & Period $^{b}$ & Topic & Citation & Citations/year \\
\hline 1. & Vargo and Lusch (2004) & 2 & Service dominant logic & 4,718 & 294.9 \\
\hline 2. & Vargo and Lusch (2008) & 2 & Service dominant logic & 2,097 & 174.8 \\
\hline 3. & Zeithaml et al. (1996) & 1 & Service quality & 3,628 & 151.2 \\
\hline 4. & Cronin et al. (2000) & 1 & Service quality & 2,219 & 111.0 \\
\hline 5. & Vargo and Lusch (2016) & 3 & Service dominant logic & 375 & 93.8 \\
\hline 6. & Payne et al. (2008) & 2 & Co-creation & 1,125 & 93.8 \\
\hline 7. & Garbarino and Johnson (1999) & 1 & Relationship marketing & 1,682 & 80.1 \\
\hline 8. & Parasuraman et al. (2005) & 2 & e-Service quality & 1,122 & 74.8 \\
\hline 9. & Sirdeshmukh et al. (2002) & 2 & Relationship marketing & 1,310 & 72.8 \\
\hline 10. & Palmatier et al. (2006) & 2 & Relationship marketing & 1,004 & 71.7 \\
\hline 11. & Hollebeek et al. (2019) & 3 & Service dominant logic & 67 & 67.0 \\
\hline 12. & Brodie et al. (2011) & 3 & Customer engagement & 579 & 64.3 \\
\hline 13. & Ostrom et al. (2015) & 3 & Research priorities & 320 & 64.0 \\
\hline 14. & Anderson et al. (1994) & 1 & Customer satisfaction & 1,750 & 67.3 \\
\hline 15. & Van Doorn et al. (2010) & 2 & Relationship marketing & 645 & 64.5 \\
\hline 16. & Fornell et al. (1996) & 1 & Customer satisfaction & 1,482 & 61.8 \\
\hline 17. & Ostrom et al. (2010) & 2 & Research priorities & 611 & 61.1 \\
\hline 18. & Brady and Cronin (2001) & 1 & Service quality & 1,080 & 56.8 \\
\hline 19. & Anderson and Sullivan (1993) & 1 & Customer satisfaction & 1,506 & 55.8 \\
\hline 20. & Lemon and Verhoef (2016) & 3 & Customer experience & 222 & 55.5 \\
\hline 21. & Lusch et al. (2007) & 2 & Service dominant logic & 656 & 50.5 \\
\hline 22. & Rust et al. (2004) & 2 & Performance & 799 & 49.9 \\
\hline 23. & Smith et al. (1999) & 1 & Failure and recovery & 1,026 & 48.9 \\
\hline 24. & Grönroos and Voima (2013) & 3 & Co-creation & 339 & 48.4 \\
\hline 25. & Edvardsson et al. (2011) & 3 & Co-creation & 432 & 48.0 \\
\hline 26. & Hennig-Thurau et al. (2002) & 2 & Relationship marketing & 864 & 48.0 \\
\hline 27. & Oliva and Kallenberg (2003) & 2 & Servitization & 814 & 47.9 \\
\hline 28. & Zeithaml et al. (2002) & 2 & e-Service quality & 848 & 47.1 \\
\hline 29. & Meuter et al. (2000) & 1 & Self-service technology & 930 & 46.5 \\
\hline 30. & Boulding et al. (1993) & 1 & Service quality & 1,246 & 46.1 \\
\hline 31. & Baker et al. (2002) & 2 & Store environment & 817 & 45.4 \\
\hline 32. & Tax et al. (1998) & 1 & Relationship marketing & 976 & 44.4 \\
\hline 33. & Moorman et al. (1993) & 1 & Relationship marketing & 1,179 & 43.7 \\
\hline 34. & Lam et al. (2004) & 2 & Relationship marketing & 696 & 43.5 \\
\hline 35. & Gwinner et al. (1998) & 1 & Relationship marketing & 946 & 43.0 \\
\hline 36. & Bolton et al. (2013) & 3 & Social media use & 288 & 41.1 \\
\hline 37. & Berry (1995) & 1 & Relationship marketing & 1,026 & 41.0 \\
\hline 38. & Zervas et al. (2017) & 3 & Sharing economy & 122 & 40.7 \\
\hline 39. & Hennig-Thurau et al. (2010) & 2 & Relationship marketing & 405 & 40.5 \\
\hline 39. & Hoyer et al. (2010) & 2 & Co-creation & 405 & 40.5 \\
\hline 39. & Keaveney (1995) & 1 & Switching behavior & 1,012 & 40.5 \\
\hline
\end{tabular}

Notes: ${ }^{a}$ The citation numbers come from the Clarivate Web of Science database (accessed on July 3, 2019). ${ }^{\text {}}$ The articles were categorized into three periods: $1=1993-2001,2=2002-2010$ and $3=2011-2019$. Articles published before 1993 are not included, even if they were very influential for the development of the service research discipline. For example, Parasuraman et al.'s $(1985,1988,1991)$ SERVQUAL scale publications have attracted 5,633 citations (160.9 citations in 1985), 6,487 (202.7 citations in 1988) and 1,377 (47.5 citations in 1991)

et al., 2017, 2019) to name but a few. Studies of these topics are still new. The research domain has the potential to grow further in terms of the number of articles. The new challenges that eservices raise should be addressed by service research.

As displayed in Figure 3, technology/e-service research also is moving from the center of the map toward a more customerfocused and operational perspective. This trend emphasizes the use of the Internet and other technologies, such as AI and robots, to establish new forms of value creation. Technology and AI can offer a key competitive advantage for service firms in the customer value creation process. Therefore, research should continue to take a strong customer perspective to study the role of technology and AI in service operations, as detailed in the specific research questions associated with this research theme in Table IV.

\section{Service-dominant logic}

The SDL is undoubtedly a star service research topic (Figure 1) as it generated great interest among marketing and service scholars during the second and third periods of the literature 
Table IV Agenda for further research

\begin{tabular}{|c|c|c|}
\hline Research themes & Related research areas & Research questions \\
\hline \multirow[t]{5}{*}{$\begin{array}{l}\text { Technology/ } \\
\text { e-service }\end{array}$} & Service robots & $\begin{array}{l}\text { - How should service robots be designed to ensure an optimal customer experience? } \\
\text { - For which types of services are robots more likely to be adopted by consumers? } \\
\text { - To what extent will Al and robots replace service employees? }\end{array}$ \\
\hline & Blockchain technology & $\begin{array}{l}\text { - Which factors are likely to influence and facilitate the use of blockchain technology in services? } \\
\text { - Which organizational characteristics are needed so that service organizations can benefit most from } \\
\text { blockchain technology to improve service quality? }\end{array}$ \\
\hline & Internet of Things (loT) & $\begin{array}{l}\text { - What is (or should be) the value-creation process for the loT? } \\
\text { - What are customers' motivations to adopt the loT in services? }\end{array}$ \\
\hline & Smart services & $\begin{array}{l}\text { - How do older consumers perceive new smart services? } \\
\text { - How can customer perceptions of privacy, security, and trust in smart connected devices be improved? } \\
\text { - To what extent can smart connected devices create new types of value (e.g., transformative value) for } \\
\text { end-users? } \\
\text { - Which factors affect consumers' adoption (or rejection) of smart services? } \\
\text { - What roles should customers play in the process of value co-creation of smart services? }\end{array}$ \\
\hline & Access-based services & $\begin{array}{l}\text { - How and when do key impediments influence customers' adoption of access-based service? } \\
\text { - What practices can access-based providers implement to encourage customers to adopt? } \\
\text { - Which practices should access-based providers implement to foster customer adoption? } \\
\text { - In which conditions is customer misbehavior more likely to occur on access-based products? } \\
\text { - What practices can firms implement to reduce (or eliminate) customer misbehavior? }\end{array}$ \\
\hline \multirow[t]{4}{*}{$\begin{array}{l}\text { Service-dominant } \\
\text { logic }\end{array}$} & Co-creation process & $\begin{array}{l}\text {-What are the antecedents and outcomes of cocreation processes between firm and its various } \\
\text { stakeholders in an Internet-enabled environment? } \\
\text { - What are the factors that influence this cocreation process? }\end{array}$ \\
\hline & $\begin{array}{l}\text { Positive and negative } \\
\text { outcomes of value co- } \\
\text { creation }\end{array}$ & $\begin{array}{l}\text { - What impacts do positive and negative outcomes of value cocreation have on the organization's overall } \\
\text { performance? }\end{array}$ \\
\hline & Transformative value & $\begin{array}{l}\text { - What kinds of service design could deliver the optimal transformative value to all stakeholders of the } \\
\text { - What are the different levels of implication of transformative value within an organization? } \\
\text { - What managerial practices can encourage the development of transformative value services within an } \\
\text { organization? }\end{array}$ \\
\hline & Dynamic capabilities & $\begin{array}{l}\text { - Which dynamic capabilities of firms support enacting SDL in service exchanges? } \\
\text { - What is the impact of SDL on the deployment of an organization's dynamic capabilities? } \\
\text { - Which factors influence the shift from a traditional strategic orientation to a service-dominant orientation } \\
\text { by firms? }\end{array}$ \\
\hline \multirow[t]{3}{*}{ Emotions } & $\begin{array}{l}\text { Role of emotions in } \\
\text { service encounters }\end{array}$ & $\begin{array}{l}\text { - Which customer emotions have the greatest influence on customer (dis)satisfaction and (dis)loyalty? } \\
\text { - How could employee and customer emotions be best measured in (1) service encounters and ( } 2 \text { ) online } \\
\text { service encounters when examining their impact on employee and customer attitudes and behaviors? }\end{array}$ \\
\hline & $\begin{array}{l}\text { Facial recognition of } \\
\text { emotions and customer } \\
\text { experience }\end{array}$ & $\begin{array}{l}\text { - Which technologies can best address customer emotions? Through which processes? } \\
\text { - How can technology-based facial recognition of customer emotions contribute to deliver a better } \\
\text { customer experience? In which conditions? } \\
\text { - How can customer discomfort with the use of technology-based facial recognition in service encounters } \\
\text { be avoided? }\end{array}$ \\
\hline & $\begin{array}{l}\text { Employees' emotional } \\
\text { responses to customer } \\
\text { emotional needs }\end{array}$ & $\begin{array}{l}\text { - How can employee emotional and behavioral skills be improved to address customers' emotional needs? } \\
\text { - Which situational factors influence the relationship between employee emotional responses to customer } \\
\text { emotional needs and customer satisfaction? }\end{array}$ \\
\hline \multirow[t]{3}{*}{ Innovation } & $\begin{array}{l}\text { Innovation and customer } \\
\text { resistance }\end{array}$ & $\begin{array}{l}\text {-Which factors prevent customers from adopting radically new services? } \\
\text { - What are the different forms of customer innovation resistance? } \\
\text { - What are the drivers of customer innovation resistance? } \\
\text { - How can (or should) firms anticipate or overcome customer innovation resistance? }\end{array}$ \\
\hline & Open innovation process & $\begin{array}{l}\text { - What roles do different stakeholders play in an organization's ecosystem in open innovation processes? } \\
\text { - How can the interaction of various stakeholders affect the outcomes of the open innovation? } \\
\text { - How can firms manage their resources to cocreate value in an open service innovation process? }\end{array}$ \\
\hline & Online service design & $\begin{array}{l}\text { - What are key motivations of customer participation in innovation-related online service design? } \\
\text { - How can customer perceptions of innovation-related online-service design affect customer satisfaction } \\
\text { and loyalty? }\end{array}$ \\
\hline
\end{tabular}




\begin{tabular}{lll}
\hline Research themes & Related research areas & Research questions \\
\hline & Co-design & - How can synergies between customers' and employees' participation in an online service co-design be \\
& & created? \\
& & What are the antecedents and outcomes of a successful co-design innovation process? \\
Environmental & Service ecosystems & - What are the factors that influence the co-design innovation process? \\
context & - How can value creation of technology can be measured in service ecosystems? \\
& - How does the interaction of the micro, meso, and macro levels of the service ecosystem influence value \\
& creation in a service? \\
& Global environmental & How does the value creation of service evolve in global and culturally diverse environmental contexts? \\
& - What impacts do customer cultural values have on perceptions of new services in global service \\
& ecosystems? \\
& - How does institutional change influence innovation systems in a global service ecosystem? \\
& - How does resource integration enhance the value creation of innovation systems in a global service \\
& ecosystem? \\
& - How does the service value proposition evolve at the micro, meso, and macro levels within dynamic \\
& service ecosystems?
\end{tabular}

review. A sub-topic that deserves further research attention pertains to cocreation. In internet-enabled environments, the value cocreation process is no longer a dyadic affair between a service organization and its customers. Rather, it occurs in extended ecosystems that include various stakeholders (Kelleher et al., 2019; Polese et al., 2017). More research is needed to clarify the roles of the various stakeholders in these complex, dynamic cocreation processes.

In service contexts, value cocreation has been depicted primarily as a result of a positive interaction between customers and service providers (Kao et al., 2016; Plé, 2016; Sweeney et al., 2015). However, such an interaction can also result in diminished or destroyed value for at least some actors in the value network, which demands consideration so that the value cocreation process can be better managed (Abney et al., 2017; Čaić et al., 2018). Furthermore, studies should examine different types of value that can be cocreated (e.g. transformative value) in greater depth (Blocker and Barrios, 2015).

According to Figure 3, SDL research is moving to become more organizationally oriented rather than consumer focused. Service firms' resources and dynamic capabilities are two crucial elements of value cocreation (Wilden et al., 2017), so integrating dynamic capabilities with SDL research could be fruitful in developing service research from an organizational perspective.

\section{Emotions}

Another star topic is the role of emotions in service delivery. Contributions from social psychology research (e.g. typologies of emotions, scales to measure emotional intelligence or emotional competence) have benefited service scholars, who use them to determine the role of emotions in service encounters (Azab et al., 2018; Delcourt et al., 2016, 2017; Fernandes et al., 2018; Hennig-Thurau et al., 2006; Liu et al., 2019). Technological innovations, such as computer-enabled facial recognition of emotions (Cowie et al., 2001), can improve the customer experience (Berry et al., 2002). Furthermore, contributions from neuroscience research (Lee et al., 2007) can help service marketers improve their efficiency and effectiveness (Fugate, 2008).

As a part of the CBM cluster, service research on emotions has experienced a U-turn, toward the center of the map. This is due to increases in recent research on emotion recognition and service performance (Doucet et al., 2016), as well as studies of how employees' emotional and behavioral responses to angry customer complaints can improve a firm's service recovery performance (Glikson et al., 2019; Jerger and Wirtz, 2017). In the future, this topic should continue to be of interest to service scholars, as the research questions in Table IV reflect.

\section{Service innovation}

The innovation theme is a question mark in Figure 1 in that it features a high growth rate but has yet to reach star status based on the number of articles published. The theme includes keywords such as pioneer advantages, new service development, time-to-market, new product adoption and new product diffusion. Considering how technological advancements contribute to the development of new services (e.g. renting autonomous cars) and the increasingly volatile, uncertain, complex and ambiguous environment in which organizations operate, research on various facets of service innovations is likely to expand. The number of publications on this topic nearly doubled between Periods 2 and 3 in the literature review. This theme is crucial for advancing service knowledge, especially considering the high failure rate due to customer resistance when organizations introduce new services (Talke and Heidenreich, 2014).

In Figure 3, the shift in innovation research, from an organizational perspective to a more consumer perspective is clear. When service firms introduce a disruptive innovation (e.g. robotic servers in the food service industry), they must anticipate perceived barriers to adoption, as well as consumers' motivations to embrace the new service form. A successful market introduction likely requires close collaboration between customers and service employees in an open service innovation 
process (Carlborg et al., 2014). Meanwhile, customer engagement in service innovation is a promising avenue for research, as indicated by the critical role of customer engagement in crowdsourcing as a means to develop new service ideas (Piyathasanan et al., 2018), online service design (Carlson et al., 2018), co-design (Sembada, 2018) and entire service ecosystems (Chandler et al., 2019). In particular, recent research on co-design signals a new customer engagement focus in innovation research (Hollebeek and Andreassen, 2018). Table IV provides specific research questions associated with this theme.

\section{Environmental context}

Environmental context is another question mark that may become a star if its growth continues. This theme and its specific topics, such as the service context and service ecosystem, have evoked increased interest due to the growing complexity of the context for international and global exchange systems (Akaka et al., 2013). This complex environment creates challenges for service organizations that also signal new research avenues. Research with a service ecosystem perspective thus is likely to contribute to a better understanding of key concepts in service research, such as innovation systems (Chandler et al., 2019; Vargo et al., 2015) and value propositions (Frow et al., 2014).

\section{Discussion}

This study was driven by three research questions. First, how has service research evolved over the past 27 years? Second, which articles have most influenced the evolution of service research over the past 27 years? And, third, what are promising service research themes for the future? By answering these questions, this article depicts service research as a mature, independent, dynamic research domain. Its core research themes include service quality, customer satisfaction and consumer behavior. Influential articles that deal with these "classic" service research topics continue to inspire new research projects, as these core themes are regularly revisited in the light of new emerging themes, such as SDL and technology/ e-services.

Service research also has emerged as an independent research domain with its own topics, such as service encounters and SDL, that integrate and adapt ideas and topics initially developed in marketing, strategic management, operations or human resource management (i.e. reflecting the four identified clusters). Finally, as a dynamic research domain, service research continues to grow and add new research themes, such as transformative service research and service robotization. In coming years, it is likely to continue to grow and evolve in new directions such as service innovation, technology and e-service and the role of emotions as described in the research agenda.

The analysis presented also suggests that, if scholars generally follow the proposed research agenda, service research may evolve in two broad, complementary directions:

1 expansion and diversification; and

2 refocusing and revisiting.

The first direction implies that service research can continue to grow, adding new research themes to its domain and exploring new research themes, whether from traditionally linked research domains (e.g. HRM) or emerging research domains in other disciplines (e.g. robotics, biometrics, cybersecurity, biostatistics). In this direction, SDL should be instrumental for developing new research projects that revisit ideas and topics originating from strategic management, operations, and HRM, or even economics, psychology and sociology. Accordingly, as the service discipline keeps expanding, subdisciplines may emerge to gain status as disciplines in their own right.

The second, complementary direction of evolution involves refocusing around core service research themes. Specifically, research is needed that revisits these topics in the light of new perspectives. Consistent with the analysis of the growth-share matrix, service research could revisit older cash cow research themes using new perspectives developed from more recent star research themes. For example, service quality (a cash cow) might be reexamined from an SDL perspective, as such a perspective may suggest a reconceptualization of the service quality construct. Similarly, service encounter research could also be revisited from a service technology perspective to develop theory about customer-robot encounters, which may be of a different nature compared to customer-employee encounters.

\section{Limitations and further research}

This review of service research literature and the proposed research agenda should be considered in light of several limitations. First, the articles appeared in a limited number of academic journals, but service research also gets published in other academic and practitioner-oriented journals (e.g. Harvard Business Review, Sloan Management Review). Therefore, the findings might be affected by a publication bias related to the publication strategy and positioning of the included journals. The careful selection of key service research journals and the large number of articles included in the database adds confidence about the representativeness of the data and the validity of the findings, yet additional research might expand the list of journals or include other types of publications to broaden the coverage.

Second, articles published before 1993 do not appear in the data set. This choice likely had little influence on the map in Figure 1 or the position of research themes, but it represents a limitation for developing the list of influential papers. A few highly cited papers published before 1993 continue to exert strong impacts, so continued research might examine a broader period (e.g. from 1953, the birth of service as a discipline; Fisk et al., 1993).

Third, the analysis of the influential articles is based on citation counts per year, a frequently used statistic to assess articles' scientific impact (Furrer et al., 2008). However, not all citations have the same importance, and articles can be cited positively or negatively (Stremersch et al., 2015). Ambiguity about the reason for a citation creates a potential for bias. However, focusing on the 41 articles with the largest average number of citations per year adds confidence that this study identifies the most influential service research articles. Continued research might find ways to differentiate positive versus negative citations of influential articles to overcome this ambiguity. 


\section{Conclusions}

By providing (1) an overview of key service research themes and their developments over time, (2) a list of the most influential articles that have shaped the evolution of service research, and (3) an agenda for research, this study offers a comprehensive overview of the evolution and future of service research.

With these findings, service scholars can better anticipate the future evolution of their research domain. They also can use the suggested research agenda to identify scholarly and managerially relevant key research topics that deserve further research attention.

\section{Notes}

1 A complete list of the 3,177 articles included in this study is available from the lead author.

2 The choice of database also is unlikely to change the findings, considering the strong correlation between the numbers of citations in the two databases (Spearman correlation coefficient, Economics and Business category: 0.93; Martín-Martín et al., 2018)

3 Table III includes 41 articles for two reasons: First, the last three articles have the same number of citations per year (40.5), and second, there is a break before the next article, which has 37.9 citations per year.

4 In addition to stars, this section focuses on question marks themes, which are somehow uncertain. Some may become stars in the future; others may regress to become pets. Out of space considerations, this discussion deals with two question marks, chosen according to their strong relative potential to become stars, as indicated by the high number of publications and high growth rate.

\section{References}

* Articles with an asterisk are included in Table III of influential articles.

Abney, A.K., White, A., Shanahan, K.J. and Locander, W.B. (2017), "In their shoes: co-creating value from deaf/hearing perspectives", fournal of Services Marketing, Vol. 31 Nos 4/5, pp. 313-325.

Akaka, M.A. and Vargo, S.L. (2015), "Extending the context of service: from encounters to ecosystems", fournal of Services Marketing, Vol. 29 Nos 6/7, pp. 453-462.

Akaka, M.A., Vargo, S.L. and Lusch, R.F. (2013), "The complexity of context: a service ecosystems approach for international marketing", fournal of International Marketing, Vol. 21 No. 4, pp. 1-20.

*Anderson, E.W. and Sullivan, M.W. (1993), "The antecedents and consequences of customer satisfaction for firms", Marketing Science, Vol. 12 No. 2, pp. 125-143.

*Anderson, E.W., Fornell, C. and Lehmann, D.R. (1994), "Customer satisfaction, market share, and profitability: findings from Sweden", fournal of Marketing, Vol. 58 No. 3, pp. 53-66.

Anderson, L., Ostrom, A.L., Corus, C., Fisk, R.P., Gallan, A.S., Giraldo, M., Mende, M., Mulder, M., Rayburn, S.W., Rosenbaum, M.S., Shirahada, K. and Williams, J.D. (2013),
"Transformative service research: an agenda for the future", Fournal of Business Research, Vol. 66 No. 8, pp. 1203-1210.

Azab, C., Clark, T. and Jarvis, C.B. (2018), "Positive psychological capabilities: the mystery ingredient in successful service recoveries?”, fournal of Services Marketing, Vol. 32 No. 7, pp. 897-912.

*Baker, J., Parasuraman, A., Grewal, D. and Voss, G.B. (2002), "The influence of multiple store environment cues on perceived merchandise value and patronage intentions", Fournal of Marketing, Vol. 66 No. 2, pp. 120-141.

Bendixen, M.T. (1995), "Compositional perceptual mapping using chi-squared trees analysis and correspondence analysis", Fournal of Marketing Management, Vol. 11 No. 6, pp. 571-581.

Benoit, S., Scherschel, K., Ates, Z., Nasr, L. and Kandampully, J. (2017), "Showcasing the diversity of service research: theories, methods, and success of service articles", Fournal of Service Management, Vol. 28 No. 5, pp. 810-836.

*Berry, L.L. (1995), "Relationship marketing of services growing interest, emerging perspectives", fournal of the Academy of Marketing Science, Vol. 23 No. 4, pp. 236-245.

Berry, L.L. and Parasuraman, A. (1993), "Building a new academic field - the case of services marketing", fournal of Retailing, Vol. 69 No. 1, pp. 13-60.

Berry, L.L., Carbone, L.P. and Haeckel, S.H. (2002), "Managing the total customer experience", MIT Sloan Management Review, Vol. 43 No. 3, pp. 85-89.

Blasius, J. and Greenacre, M. (2006), "Correspondence analysis and related methods in practice", in Greenacre, $M$. and Blasius, J. (Eds), Multiple Correspondence Analysis and Related Methods, Chapman and Hall/CRC, Boca Raton, FL, pp. 3-40.

Blocker, C.P. and Barrios, A. (2015), "The transformative value of a service experience", fournal of Service Research, Vol. 18 No. 3, pp. 265-283.

*Bolton, R.N., Parasuraman, A., Hoefnagels, A., Migchels, N., Kabadayi, S., Gruber, T., Komarova Loureiro, Y. and Solnet, D. (2013), "Understanding generation Y and their use of social media: a review and research agenda", fournal of Service Management, Vol. 24 No. 3, pp. 245-267.

*Boulding, W., Kalra, A., Staelin, R. and Zeithaml, V.A. (1993), "A dynamic process model of service quality: from expectations to behavioral intentions", fournal of Marketing Research, Vol. 30 No. 1, pp. 7-27.

Bowen, D.E. and Schneider, B. (2014), "A service climate synthesis and future research agenda", fournal of Service Research, Vol. 17 No. 1, pp. 5-22.

*Brady, M.K. and Cronin, J.J. Jr., (2001), "Some new thoughts on conceptualizing perceived service quality: a hierarchical approach", Fournal of Marketing, Vol. 65 No. 3, pp. 34-49.

Brax, S. (2005), "A manufacturer becoming service provider challenges and a paradox", Managing Service Quality: An International fournal, Vol. 15 No. 2, pp. 142-155.

Brodie, R.J., Whittome, J.R. and Brush, G.J. (2009), "Investigating the service brand: a customer value perspective", fournal of Business Research, Vol. 62 No. 3, pp. 345-355.

*Brodie, R.J., Hollebeek, L.D., Jurić, B. and Ilić, A. (2011), "Customer engagement: conceptual domain, fundamental 
propositions, and implications for research", fournal of Service Research, Vol. 14 No. 3, pp. 252-271.

Čaić, M., Odekerken-Schröder, G. and Mahr, D. (2018), "Service robots: value co-creation and co-destruction in elderly care networks", fournal of Service Management, Vol. 29 No. 2, pp. 178-205.

Carlborg, P., Kindström, D. and Kowalkowski, C. (2014), "The evolution of service innovation research: a critical review and synthesis", The Service Industries fournal, Vol. 34 No. 5, pp. 373-398.

Carlson, J., Rahman, M., Voola, R. and De Vries, N. (2018), "Customer engagement behaviours in social media: capturing innovation opportunities", Fournal of Services Marketing, Vol. 32 No. 1, pp. 83-94.

Chandler, J.D., Danatzis, I., Wernicke, C., Akaka, M.A. and Reynolds, D. (2019), "How does innovation emerge in a service ecosystem?", Fournal of Service Research, Vol. 22 No. 1, pp. 75-89.

Cicchetti, D.V. (1994), "Guidelines, criteria, and rules of thumb for evaluating normed and standardized assessment instruments in psychology", Psychological Assessment, Vol. 6 No. 4, pp. 284-290.

Cowie, R., Douglas-Cowie, E., Tsapatsoulis, N., Votsis, G., Kollias, S., Fellenz, W. and Taylor, J.G. (2001), "Emotion recognition in human-computer interaction", IEEE Signal Processing Magazine, Vol. 18 No. 1, pp. 32-80.

*Cronin, J.J., Jr., Brady, M.K. and Hult, G.T.M. (2000), "Assessing the effects of quality, value, and customer satisfaction on consumer behavioral intentions in service environments", fournal of Retailing, Vol. 76 No. 2, pp. 193-218.

De Keyser, A., Köcher, S., Alkire, L., Verbeeck, C. and Kandampully, J. (2019), "Frontline service technology infusion: conceptual archetypes and future research directions", fournal of Service Management, Vol. 30 No. 1, pp. 156-183.

Delcourt, C., Gremler, D.D., De Zanet, F. and van Riel, A.C. R. (2017), "An analysis of the interaction effect between employee technical and emotional competencies in emotionally charged service encounters", fournal of Service Management, Vol. 28 No. 1, pp. 85-106.

Delcourt, C., Gremler, D.D., van Riel, A.C.R. and van Birgelen, M.J.H. (2016), "Employee emotional competence: construct conceptualization and validation of a customerbased measure", Fournal of Service Research, Vol. 19 No. 1, pp. $72-87$.

Doucet, L., Shao, B., Wang, L. and Oldham, G.R. (2016), "I know how you feel, but it does not always help: integrating emotion recognition, agreeableness, and cognitive ability in a compensatory model of service performance", fournal of Service Management, Vol. 27 No. 3, pp. 320-338.

*Edvardsson, B., Tronvoll, B. and Gruber, T. (2011), "Expanding understanding of service exchange and value co-creation: a social construction approach", fournal of the Academy of Marketing Science, Vol. 39 No. 2, pp. 327-339.

Fernandes, T., Morgado, M. and Rodrigues, M.A. (2018), "The role of employee emotional competence in service recovery encounters", fournal of Services Marketing, Vol. 32 No. 7 , pp. 835-849.
Fisk, R.P., Brown, S.W. and Bitner, M.J. (1993), "Tracking the evolution of the services marketing literature", fournal of Retailing, Vol. 69 No. 1, pp. 61-103.

Fisk, R.P., Grove, S.J. and John, J. (2000), "Services marketing self-portraits: Introspections", Reflections, and Glimpses from the Experts, American Marketing Association, Chicago.

${ }^{*}$ Fornell, C., Johnson, M.D., Anderson, E.W., Cha, J. and Bryant, B.E. (1996), "The American customer satisfaction index: nature, purpose, and findings", fournal of Marketing, Vol. 60 No. 4, pp. 7-18.

Frow, P., McColl-Kennedy, J.R., Hilton, T., Davidson, A., Payne, A. and Brozovic, D. (2014), "Value propositions: a service ecosystems perspective", Marketing Theory, Vol. 14 No. 3, pp. 327-351.

Fugate, D.L. (2008), "Marketing services more effectively with neuromarketing research: a look into the future", fournal of Services Marketing, Vol. 22 No. 2, pp. 170-173.

Furrer, O. and Sollberger, P. (2007), "The dynamics and evolution of the service marketing literature: 1993-2003", Service Business, Vol. 1 No. 2, pp. 93-117.

Furrer, O., Thomas, H. and Goussevskaia, A. (2008), "The structure and evolution of the strategic management field: a content analysis of 26 years of strategic management research", International fournal of Management Reviews, Vol. 10 No. 1, pp. 1-23.

*Garbarino, E. and Johnson, M. (1999), "The different roles of satisfaction, trust, and commitment in customer relationships", Fournal of Marketing, Vol. 63 No. 2, pp. 70-87.

Glikson, E., Rees, L., Wirtz, J., Kopelman, S. and Rafaeli, A. (2019), "When and why a squeakier wheel gets more grease? The influence of cultural values and anger intensity on customer compensation", fournal of Service Research, Vol. 22 No. 3, pp. 223-240.

*Grönroos, C. and Voima, P. (2013), "Critical service logic: making sense of value creation and co-creation", fournal of the Academy of Marketing Science, Vol. 41 No. 2, pp. 133-150.

Grove, S.J., Fisk, R.P. and John, J. (2003), "The future of services marketing: forecasts from ten services experts", Fournal of Services Marketing, Vol. 17 No. 2, pp. 107-121.

${ }^{*}$ Gwinner, K.P., Gremler, D.D. and Bitner, M.J. (1998), "Relational benefits in services industries: the customer's perspective", Fournal of the Academy of Marketing Science, Vol. 26 No. 2, pp. 101-114.

Hair, J.F., Black, W.C., Babin, B.J. and Anderson, R.E. (2010), Multivariate Data Analysis: A Global Perspective, 7th ed., Pearson, Upper Saddle River.

Hazée, S., Delcourt, C. and Van Vaerenbergh, Y. (2017), "Burdens of access: understanding customer barriers and barrier-attenuating practices in access-based services", Fournal of Service Research, Vol. 20 No. 4, pp. 441-456.

Hazée, S., Van Vaerenbergh, Y., Delcourt, C. and Warlop, L. (2019), "Sharing goods? yuck, no! an investigation of consumers' contamination concerns about access-based services", fournal of Service Research, Vol. 22 No. 3, pp. 256-271.

${ }^{*}$ Hennig-Thurau, T., Groth, M., Paul, M. and Gremler, D.D. (2006), "Are all smiles created equal? how employeecustomer emotional contagion and emotional labor impact 
service relationships", fournal of Marketing, Vol. 70 No. 3, pp. 58-73.

${ }^{*}$ Hennig-Thurau, T., Gwinner, K.P. and Gremler, D.D. (2002), "Understanding the relationship between marketing outcomes: an integration of relational benefits and relationship quality", Fournal of Service Research, Vol. 4 No. 3, pp. 230-247.

Hennig-Thurau, T., Malthouse, E.C., Friege, C., Gensler, S., Lobschat, L., Rangaswamy, A. and Skiera, B. (2010), "The impact of new media on customer relationships", fournal of Service Research, Vol. 13 No. 3, pp. 311-330.

Hoffman, D.L. and De Leeuw, J. (1992), "Interpreting multiple correspondence analysis as a multidimensional scaling method", Marketing Letters, Vol. 3 No. 3, pp. 259-272.

Hoffman, D.L. and Franke, G.R. (1986), “Correspondence analysis: graphical representation of categorical data in marketing research", fournal of Marketing Research, Vol. 23 No. 3, pp. 213-227.

*Hollebeek, L.D. and Andreassen, T.W. (2018), "The S-D logic-informed 'hamburger' model of service innovation and its implications for engagement and value", fournal of Services Marketing, Vol. 32 No. 1, pp. 1-7.

Hollebeek, L.D., Srivastava, R.K. and Chen, T. (2019), "SD logic-informed customer engagement: integrative framework, revised fundamental propositions, and application to CRM", Fournal of the Academy of Marketing Science, Vol. 47 No. 1, pp. 161-185.

*Hoyer, W.D., Chandy, R., Dorotic, M., Krafft, M. and Singh, S.S. (2010), "Consumer cocreation in new product development”, fournal of Service Research, Vol. 13 No. 3, pp. 283-296.

Huang, M.H. and Rust, R.T. (2018), "Artificial intelligence in service", Fournal of Service Research, Vol. 21 No. 2, pp. 155-172.

Huber, J., Kamakura, W. and Mela, C.F. (2014), “A topical history of JMR", fournal of Marketing Research, Vol. 51 No. 1, pp. 84-91.

Inkpen, A.C. and Beamish, P.W. (1994), "An analysis of twenty-five years of research in the journal of international business studies", Fournal of International Business Studies, Vol. 25 No. 4, pp. 703-713.

Jerger, C. and Wirtz, J. (2017), "Service employee responses to angry customer complaints: the roles of customer status and service climate", fournal of Service Research, Vol. 20 No. 4, pp. 362-378.

Kaciak, E. and Louviere, J. (1990), "Multiple correspondence analysis of multiple choice experiment data", fournal of Marketing Research, Vol. 27 No. 4, pp. 455-465.

Kao, T.Y., Yang, M.H., Wu, J.T.B. and Cheng, Y.Y. (2016), "Co-creating value with consumers through social media", Fournal of Services Marketing, Vol. 30 No. 2, pp. 141-151.

*Keaveney, S.M. (1995), "Customer switching behavior in service industries: an exploratory study", fournal of Marketing, Vol. 59 No. 2, pp. 71-82.

Kelleher, C., Wilson, H.N., Macdonald, E.K. and Peppard, J. (2019), "The score is not the music: integrating experience and practice perspectives on value co-creation in collective consumption contexts", fournal of Service Research, Vol. 22 No. 2, pp. 120-138.
Koku, P.S. (2019), “A viewpoint from the trenches", fournal of Services Marketing, Vol. 33 No. 1, pp. 125-130.

Kunz, W.H. and Hogreve, J. (2011), "Toward a deeper understanding of service marketing: the past, the present, and the future", International fournal of Research in Marketing, Vol. 28 No. 3, pp. 231-247.

*Lam, S.Y., Shankar, V., Erramilli, M.K. and Murthy, B. (2004), "Customer value, satisfaction, loyalty, and switching costs: an illustration from a business-to-business service context", Fournal of the Academy of Marketing Science, Vol. 32 No. 3, pp. 293-311.

Larivière, B., Bowen, D., Andreassen, T.W., Kunz, W., Sirianni, N.J., Voss, C., Wünderlich, N.V. and De Keyser, A. (2017), “'Service encounter 2.0': an investigation into the roles of technology, employees and customers", fournal of Business Research, Vol. 79 No. 10, pp. 238-246.

Lebart, L., Morineau, A. and Warwick, K.M. (1984), Multivariate Descriptive Statistical Analysis: Correspondence Analysis and Related Techniques for Large Matrices, Wiley, New York, NY.

Lee, N., Broderick, A.J. and Chamberlain, L. (2007), "What is 'neuromarketing'? A discussion and agenda for future research", International fournal of Psychophysiology, Vol. 63 No. 2, pp. 199-204.

*Lemon, K.N. and Verhoef, P.C. (2016), "Understanding customer experience throughout the customer journey", Fournal of Marketing, Vol. 80 No. 6, pp. 69-96.

Liu, X.Y., Chi, N.W. and Gremler, D.D. (2019), "Emotion cycles in services: emotional contagion and emotional labor effects", Fournal of Service Research, Vol. 22 No. 3, pp. 285-300.

*Lusch, R.F., Vargo, S.L. and O'Brien, M. (2007), "Competing through service: insights from servicedominant logic”, fournal of Retailing, Vol. 83 No. 1, pp. 5-18.

Mai, R. and Hoffmann, R. (2011), "Four positive effects of a salesperson's regional dialect in services selling", fournal of Service Research, Vol. 14 No. 4, pp. 460-474.

Martín-Martín, A., Orduna-Malea, E., Thelwall, M. and López-Cózar, E.D. (2018), "Google scholar, web of science, and scopus: a systematic comparison of citations in 252 subject categories", fournal of Informetrics, Vol. 12 No. 4, pp. 1160-1177.

Meulman, J.J. and Heisen, W.J. (2017), IBM SPSS Categories 25, SPSS, Chicago.

* Meuter, M.L., Ostrom, A.L., Roundtree, R.I. and Bitner, M.J. (2000), "Self-service technologies: understanding customer satisfaction with technology-based service encounters", Fournal of Marketing, Vol. 64 No. 3, pp. 50-64.

*Moorman, C., Deshpandé, R. and Zaltman, G. (1993), "Factors affecting trust in market research relationships", fournal of Marketing, Vol. 57 No. 1, pp. 81-101.

Nel, D., Van Heerden, G., Chan, A., Ghazisaeedi, M., Halvorson, W. and Steyn, P. (2011), "Eleven years of scholarly research in the journal of services marketing", Fournal of Services Marketing, Vol. 25 No. 1, pp. 4-13.

$\mathrm{Ng}$, I.C.L. and Wakenshaw, S.Y.L. (2017), “The internet-ofthings: review and research directions", International fournal of Research in Marketing, Vol. 34 No. 1, pp. 3-21.

Ng, I.C.L., Maull, R. and Smith, L. (2011), "Embedding the new discipline of service science", in Demirkan, H., Spohrer, 
J.C. and Krishna, V. (Eds), The Science of Service Systems, Springer, Dordrecht, pp. 13-35.

*Oliva, R. and Kallenberg, R. (2003), "Managing the transition from products to services", International fournal of Service Industry Management, Vol. 14 No. 2, pp. 160-172.

*Ostrom, A.L., Bitner, M.J., Brown, S.W., Burkhard, K.A., Goul, M., Smith-Daniels, V., Demirkan, H. and Rabinovich, E. (2010), "Moving forward and making a difference: research priorities for the science of service", Fournal of Service Research, Vol. 13 No. 1, pp. 4-36.

*Ostrom, A.L., Parasuraman, A., Bowen, D.E., Patricio, L. and Voss, C.A. (2015), "Service research priorities in a rapidly changing context", fournal of Service Research, Vol. 18 No. 2, pp. 127-159.

*Palmatier, R.W., Dant, R.P., Grewal, D.D. and Evans, K.R. (2006), "Factors influencing the effectiveness of relationship marketing: a meta-analysis", fournal of Marketing, Vol. 70 No. 4, pp. 136-153.

Parasuraman, A., Berry, L.L. and Zeithaml, V.A. (1991), "Refinement and reassessment of the SERVQUAL scale", Fournal of Retailing, Vol. 67 No. 4, pp. 420-450.

Parasuraman, A., Zeithaml, V.A. and Berry, L.L. (1985), “A conceptual model of service quality and its implications for future research", fournal of Marketing, Vol. 49 No. 4, pp. 41-50.

Parasuraman, A., Zeithaml, V.A. and Berry, L.L. (1988), "SERVQUAL: a multiple-item scale for measuring consumer perceptions of service quality", fournal of Retailing, Vol. 64 No. 1, pp. 12-37.

*Parasuraman, A., Zeithaml, V.A. and Malhotra, A. (2005), "ES-QUAL: a multiple-item scale for assessing electronic service quality", fournal of Service Research, Vol. 7 No. 3, pp. 213-233.

*Payne, A.F., Storbacka, K. and Frow, P. (2008), "Managing the co-creation of value", fournal of the Academy of Marketing Science, Vol. 36 No. 1, pp. 83-96.

Perreault, W.D., Jr. and Leigh, L.E. (1989), "Reliability of nominal data based on qualitative judgments", fournal of Marketing Research, Vol. 26 No. 2, pp. 135-148.

Piyathasanan, B., Mathies, C., Patterson, P.G. and de Ruyter, K. (2018), "Continued value creation in crowdsourcing from creative process engagement", Fournal of Services Marketing, Vol. 32 No. 1, pp. 19-33.

Plé, L. (2016), "Studying customers' resource integration by service employees in interactional value co-creation", Fournal of Services Marketing, Vol. 30 No. 2, pp. 152-164.

Polese, F., Mele, C. and Gummesson, E. (2017), "Value cocreation as a complex adaptive process", fournal of Service Theory and Practice, Vol. 27 No. 5, pp. 926-929.

Popli, S. and Rizvi, I.A. (2015), "Exploring the relationship between service orientation, employee engagement and perceived leadership style: a study of managers in the private service sector organizations in India", fournal of Services Marketing, Vol. 29 No. 1, pp. 59-70.

*Rust, R.T., Lemon, K.N. and Zeithaml, V.A. (2004), "Return on marketing: using customer equity to focus marketing strategy", fournal of Marketing, Vol. 68 No. 1, pp. 109-127.

Sembada, A. (2018), "The two sides of empowering consumers to co-design innovations", fournal of Services Marketing, Vol. 32 No. 1, pp. 8-18.
*Sirdeshmukh, D., Singh, J. and Sabol, B. (2002), "Consumer trust, value, and loyalty in relational exchanges", fournal of Marketing, Vol. 66 No. 1, pp. 15-37.

*Smith, A.K., Bolton, R.N. and Wagner, J. (1999), “A model of customer satisfaction with service encounters involving failure and recovery", fournal of Marketing Research, Vol. 36 No. 3, pp. 356-372.

Stremersch, S., Camacho, N., Vanneste, S. and Verniers, I. (2015), "Unraveling scientific impact: citation types in marketing journals", International fournal of Research in Marketing, Vol. 32 No. 1, pp. 64-77.

Sweeney, J.C., Danaher, T.S. and McColl-Kennedy, J.R. (2015), "Customer effort in value cocreation activities: improving quality of life and behavioral intentions of health care customers", fournal of Service Research, Vol. 18 No. 3, pp. 318-335.

Talke, K. and Heidenreich, S. (2014), "How to overcome prochange bias: incorporating passive and active innovation resistance in innovation decision models", fournal of Product Innovation Management, Vol. 31 No. 5, pp. 894-907.

Tapscott, D. and Tapscott, A. (2017), "How blockchain will change organizations", MIT Sloan Management Review, Vol. 58 No. 2, pp. 10-13.

*Tax, S.S., Brown, S.W. and Chandrashekaran, M. (1998), "Customer evaluations of service complaint experiences: implications for relationship marketing", fournal of Marketing, Vol. 62 No. 2, pp. 60-76.

Thompson, A.M.K. (2010), "Golder's historical method in research in marketing", fournal of Business Research, Vol. 63 No. 12, pp. 1269-1272.

*Van Doorn, J., Lemon, K.N., Mittal, V., Nass, S., Pick, D., Pirner, P. and Verhoef, P.C. (2010), "Customer engagement behavior: theoretical foundations and research directions", Fournal of Service Research, Vol. 13 No. 3, pp. 253-266.

Van Doorn, J., Mende, M., Noble, S.M., Hulland, J., Ostrom, A.L., Grewal, D. and Petersen, J.A. (2017), "Domo arigato Mr. Roboto: emergence of automated social presence in organizational frontlines and customers' service experiences", Fournal of Service Research, Vol. 20 No. 1, pp. 43-58.

*Vargo, S.L. and Lusch, R.F. (2004), "Evolving to a new dominant logic for marketing", fournal of Marketing, Vol. 68 No. 1, pp. 1-17.

*Vargo, S.L. and Lusch, R.F. (2008), "Service-dominant logic: continuing the evolution", fournal of the Academy of Marketing Science, Vol. 36 No. 1, pp. 1-10.

Vargo, S.L. and Lusch, R.F. (2016), "Institutions and axioms: an extension and update of service-dominant logic", fournal of the Academy of Marketing Science, Vol. 44 No. 1, pp. 5-23.

Vargo, S.L., Wieland, H. and Akaka, M.A. (2015), "Innovation through institutionalization: a service ecosystems perspective", Industrial Marketing Management, Vol. 44 No. 1, pp. 63-72.

Wang, X., Bendle, N.T., Mai, F. and Cotte, J. (2015), "The journal of consumer research at 40: a historical analysis", Fournal of Consumer Research, Vol. 42 No. 1, pp. 5-18.

Wilden, R., Akaka, M.A., Karpen, I.O. and Hohberger, J. (2017), "The evolution and prospects of service-dominant logic: an investigation of past, present, and future research", Fournal of Service Research, Vol. 20 No. 4, pp. 345-361. 
Wirtz, J., Patterson, P.G., Kunz, W.H., Gruber, T., Lu, V.N., Paluch, S. and Martins, A. (2018), "Brave new world: service robots in the frontline", fournal of Service Management, Vol. 29 No. 5, pp. 907-931.

Wünderlich, N.V., Heinonen, K., Ostrom, A.L., Patricio, L., Sousa, R., Voss, C. and Lemmink, J.G.A.M. (2015), "Futurizing' smart service: implications for service researchers and managers", fournal of Services Marketing, Vol. 29 Nos 6/7, pp. 442-447.

Zablah, A.R., Sirianni, N.J., Korschun, D., Gremler, D.D. and Beatty, S.E. (2017), "Emotional convergence in service relationships: the shared frontline experience of customers and employees", fournal of Service Research, Vol. 20 No. 1, pp. 76-90.
*Zeithaml, V.A., Berry, L.L. and Parasuraman, A. (1996), "The behavioral consequences of service quality", fournal of Marketing, Vol. 60 No. 2, pp. 31-46.

*Zeithaml, V.A., Parasuraman, A. and Malhotra, A. (2002), "Service quality delivery through web sites: a critical review of extant knowledge", Fournal of the Academy of Marketing Science, Vol. 30 No. 4, pp. 362-375.

*Zervas, G., Proserpio, D. and Byers, J.W. (2017), "The rise of the sharing economy: estimating the impact of airbnb on the hotel industry", Fournal of Marketing Research, Vol. 54 No. 5, pp. 687-705.

\section{Corresponding author}

Olivier Furrer can be contacted at: olivier.furrer@unifr.ch 